\title{
Både insats och relation spelar roll
}

Spelar valet av behandlingsinsats någon roll i socialt arbete? Anders Bergmark och Tommy Lundström tycks mena att så inte är fallet utan att effekter av psykosociala insatser beror på generella faktorer, såsom alliansen mellan terapeut och klient. I en bok från 2009 beskriver Bergmark konsekvenserna av denna slutsats:

"Viborde sluta med eller begränsa genomförandet av RCT-studier som jämför utfallet av olika typer av behandlingsinterventioner. Vi bör sluta betona nödvändigheten av manualer som ett medel för genomförandet av specifika terapeutiska ingredienser, och möjligen kanske också överge hela idén om EBP (min kommentar: evidensbaserad praktik)" (s. 62).

Bergmark menar med andra ord att ALLA insatser är lika effektiva, givet att de generella faktorerna är gynnsamma.

\section{Kan terapeutisk allians förhindra skadliga insatser?}

Om det finns både skadliga och ickeskadliga insatser så är alla insatser inte lika effektiva. För beteendestörda barn och unga finns en rad insatser, inklusive Attachment-terapi. Attachment-terapi inkluderar Holding som innebär att föräldrarna håller fast barnet i sin famn med alla krafter så att det inte kommer loss, vilket antas frigöra gamla känslor och göra barnet redo för att utveckla nya positiva känslor till föräldrarna. En annan version av Attachmentterapi är Rebirthing som innebär att barnet rullas in hårt i filtar som flera vuxna håller i, samtidigt som man pressar och trycker på för att simulera en normal vaginal förlossning. Tanken är att barnet ska komma ut "pånyttfödd" och öppen för en ny anknytning till föräldrarna.

Ingen av dessa varianter av Attachmentterapi har vad jag vet utvärderats. Däremot används de av terapeuter. Holdingterapeuter finns också i Sverige. För några år sedan uppdagades att ett behandlingshem använde Holding och att en flicka fått armen bruten när hon försökte ta sig fri. Det förekom att man hållit fast ungdomar i upp till sex timmar. I USA kvävdes den tioåriga flickan Candace Newmaker till döds av sina föräldrar år 2000. Det skedde i samband med att föräldrarna tillämpade Rebirthing och under överinseende av professionella terapeuter (Kennedy, Mercer, Mohr \& Huffine 2002).

Om vi ska tro Bergmark och Lundström är Attachment-terapi således lika effektivt som andra insatser för denna målgrupp som har ett vetenskapligt stöd (jfr SBU 2010). Finns det skadliga insatser enligt Bergmark och Lundström? Om så är fallet 
kan det skadliga alltid uppvägas av en god terapeutisk allians?

För andra exempel på skadliga insatser hänvisas läsaren till exempelvis Lilienfeld (2007).

\section{Generella och specifika faktorer är båda viktiga}

Socialstyrelsens position, baserad på den vetenskapliga evidens som är tillgänglig, är att insatser ("specifika faktorer") spelar roll liksom också generella faktorer. Det är inte antingen eller utan både och. I den Socialstyrelserapport (2011) som är utgångspunkten för Bergmark och Lundströms debattartikel betonar författarna:

"Det är viktigt att notera att kritiken mot Dodofågelns hypotes inte innebär att generella faktorer saknar betydelse. Tuärtom finns en bred enighet om att generella faktorer är viktiga, och då inte minst den terapeutiska alliansen mellan behandlare och klient" (s. 13).

Jag överlåter till läsaren att själv ta ställning i fråga om val av insats spelar roll genom att exempelvis ta del av de referenser som finns i Socialstyrelsens rapport som kan laddas ner från vår hemsida. Själv ser jag dock ingen anledning till att ompröva rapportförfattarnas slutsats.

Bergmark och Lundström är upprörda över att Socialstyrelsen tar ställning i en vetenskaplig kontrovers som denna. Jag kan inte se detta som något märkligt. Om inte Socialstyrelsen tog ställning i vetenskapliga kontroverser - vilka är legio - skulle vi inte kunna fullfölja vårt uppdrag att värna hälsa, välfärd och allas lika tillgång till god vård och omsorg, baserat på kunskap. I ljuset av den forskning som finns om specifika och generella faktorer bedömer vi att valet av insats spelar roll.

\section{Konfrontativ debattstil}

Bergmark och Lundström (2011) har en konfrontativ debattstil. Till exempel skriver de att "Socialstyrelsens ställningstagande tycks oss med andra ord för grovt och förenklat /.../ man kan fråga sig varför detta arbete beställts och viken position det har i myndigheten" (s. 250). Därmed tillskriver de professorskollegorna från USA låg kompetens och tycks tro att Socialstyrelsen beställt denna rapport med ett försåtligt syfte. Så är inte fallet. Socialstyrelsens uppdrag kräver ofta vetenskapliga underlag. Vi ger därför regelbundet uppdrag till ledande forskare, både svenska och internationella. Eftersom frågan om specifika och generella faktorers betydelse är viktig för det sociala arbetets utveckling sökte vi forskare med överblick över den internationella forskningen om psykosociala insatsers effekter. Dessutom sökte vi forskare som inte redan bestämt hur den framtida forskningen ska avgränsas - i motsats till Bergmark som redan 2009 slagit fast att Dodofågelns hypotes är sanning och att det som gäller för psykoterapi också gäller för socialt arbete i sin helhet.

Forskning är en färskvara och de internationella forskarnas rapport betonar vikten av fortsatt forskning om vilken insats som fungerar för vilka klienter och problem och 
under vilka förutsättningar. Skulle forskningsläget drastiskt förändras och visa att alla insatser är lika effektiva så kommer Socialstyrelsen skyndsamt att informera socialarbetare och andra professioner om det.

Man kan fråga sig om bakgrunden till det uppskruvade tonläget i denna och tidigare debattartiklar av Bergmark och Lundström. Kanske ger professor Lars Oscarsson (2011) svaret i en nyutkommen bok. Oscarsson för fram tanken att en "individ- och effektfokuserad förståelse av sociala problem och socialt arbete" och därmed tillhörande forskning om insatsers effekter, hotar disciplinen socialt arbete eftersom det då finns "andra ämnen och andra professioner, såsom läkare och psykologer, med större legitimitet i samhället att både beforska och ta hand om den typen av problem" (s. 195).

\section{Knut Sundell}

Docent och socialråd på Socialstyrelsen

\section{Referenser}

Bergmark, A. (2009). Den evidensbaserade praktikens gränser - om konsekvenserna av "the Dodo bird verdict”, I K. Billinger \& L. Hubner (red.), Alkohol och droger. Samhällsvetenskapliga perspektiv (s. 55-66). Malmö: Gleerups.

Bergmark, A. \& Lundström, T. (2011). Socialstyrelsen, dronten och den evidensbaserade praktiken. Socialvetenskapligtidskrift, 3, 244-250.

Kennedy, S. S., Mercer, J., Mohr, W. \& Huffine, C. W. (2002). Snake oil, ethics, and the First Amendment: What's a profession to do? American Journal of Orthopsychiatry, 72, 5-15.

Lilienfeld, S. O. (2007). Psychological treatments that cause harm. Perspectives on psychological science, 2, 53-70.
Mullen, E. J., Shuluk, J., \& Soydan, H. (2011). Debatten om Dodo-fägeln - spelar behandlingsmetoden någon roll i klientarbete? Stockholm: Socialstyrelsen. www.socialstyrelsen.se/publikationer2011/2011-4-15

Oscarsson, L. (2011). Utvärdering och evidensbasering. I B. Blom, S. Morén \& L. Nygren (red.). Utvärdering $i$ socialt arbete: Utgaingspunkter, modeller och användning (s. 183-198). Stockholm: Natur och kultur.

SBU (2010). Program för att förebygga psykisk ohälsa hos barn. En systematisk litteraturöversikt. Stockholm: Statens beredning för medicinsk utvärdering (SBU); SBU-rapport nr 202. ISBN 978-91-85413-38-6. 